\title{
Comparison of oncological results after curative resection in right and left colon cancers
}

\author{
Eyüp Murat Yilmaz'1, Erkan Karacan², Buse Yildiz' ${ }^{1}$, Murat Demir ${ }^{1}$, Ahmet Ender Demirkiran ${ }^{1}$
}

${ }^{1}$ Department of General Surgery, Adnan Menderes University Faculty of Medicine, Aydin, Turkey ${ }^{2}$ Department of General Surgery, Aydin State Hospital, Aydin, Turkey

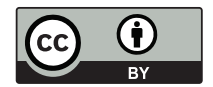

This work is licensed under a Creative Commons Attribution 4.0 International License

\section{Received: 2020-04-02}

Accepted: 2020-04-10

UDC: 618.1

\section{J Clin Med Kaz 2020; 2(56):41-45}

Corresponding Author: Eyüp Murat Yilmaz, Department of General Surgery, Faculty of Medicine, Adnan Menderes University, Aydin, Turkey.

Tel.: +905056005995

E-mail: drmyilmaz80@gmail.com
Abstract

Background: Right colon and left colon cancers have different genetic and clinical characteristics. It is thought that right colon cancers have more aggressive course.

Aim: We planned to compare differences between right and left colon cancers, oncological results, survival rate after curative resection.

Material and methods: The patients who had been operated between January 2015 and December 2019 were included in the study, and they were separated into two groups as right colon and left colon cancers. The files of the patients were scanned, and in addition to the demographic data, the tumor stages according to the tumor, nodus, metastasis staging, the number of lymph nodes removed, the type of the operation (laparoscopic/open), average follow-up time, metastasis, recurrence and death/survival were recorded and compared.

Results: A total of 76 patients were included, and 38 (50\%) were diagnosed with right colon cancer whereas $38(50 \%)$ had left colon cancer. The average follow-up time was found as 17.14 months ( 1 - 60 months). While no difference was detected between the two groups in neurovascular invasion, the mean number of lymphovascular invasion positivity was found as $18.34 \pm 4.16$ and $13.34 \pm 5.45$ in two groups, respectively $(\mathrm{p}<0.05)$. All the recurrences $(5)$ were found in right colon tumors, no recurrence was observed in left colon tumors $(\mathrm{p}=0.021)$. When the metastasis and death rates were examined, no statistically significant difference was seen between the two groups.

Conclusion: We observe that lymphovascular invasion and recurrence rates are higher in right colon cancers compared to left colon cancers.

Key words: colon cancer, left colon, oncolocigal results, recurrence, right colon, survival rate

ӨСІП КЕЛЕ ЖОҒАРЫЛАГАН ЖИЕК ІШЕК ЖӘНЕ ТӨМЕНДЕГЕН ЖИЕК ІШЕК ҚАТЕРЛІ ІСІГІНДЕГІ КЛИНИКАЛЫҚ РАДИКАЛДЫ РЕЗЕКЦИЯДАН КЕЙІНГІ ОНКОЛОГИЯЛЫҚ НӘТИЖЕЛЕРДІ САЛЫСТЫРУ

Э.М. Йылмаз ${ }^{1}$, Э. Каракан ${ }^{2}$, Б. Йылдыз ${ }^{1}$, М. Демир ${ }^{1}$, А.Э. Демиркиран ${ }^{1}$

'Жалпы хирургия кафедрасы, Аднан Мендерес атындағы университет, Айдын, Түркия

²Жалпы хирургия бөілімі, Мемлекеттік аурухана, Айдын, Түркия

\section{ТҰЖЫРЫМДАМА}

Кіріспе: Жоғарылаған және төмендеген жиек ішектің қатерлі ісігі әртүрлі генетикалық және клиникалық сипаттамаларға ие. Көтерілетін жиек ішектің қатерлі ісігі анағұрлым агрессивті бағытқа ие деп саналады.

Мақсаты: жоғарылаған және төмендеген жиек ішек қатерлі ісігінің, онкологиялық нәтижелердің, клиникалық радикалды резекциядан кейін тірі қалудың айырмашылығын салыстыру.

Материалдар мен әдістер: 2015 жылдың қаңтарынан бастап 2019 жылдың желтоқсанына дейін ота жасалынған пациенттер зерттеуге қосылды және джоғарылаған және төмендеген жиек ішегінің қатерлі ісігі деп екі топқа бөлінді.

Науқастардың медициналық қарталары зерттелді, демографиялық мәліметтерге қосымша, ісік, түйін, метастаз, ісіктің сатысы, жойылған лимфа түйіндерінің саны, операция түрі (лапароскопиялық / ашық), орташа бақылау, метастаздар, рецидивтерге және өлім/тірі қалуға байланысты ақпарат жазылып, салыстырылды.

Нәтижелер: Зерттеуге барлығы 76 науқас енгізілді, 38-ге (50\%) жоғарылаған жиек ішектің қатерлі ісігі диагнозы қойылды, ал 38 (50\%) төмендеген жиек ішектің қатерлі ісігі анықталды. Орташа бақылау 17,14 айды (1-60 ай) құрады.

Екі топ арасында жүйке тамырлық инвазияға қатысты ешқандай айырмашылықтар болмағанына қарамастан, екі топта лимфоиамырлық инвазиялардың позитивтілігінің орташа мәні $18,34 \pm$ 4,16 және 13,34 \pm 5,45 болды (p <0.05 ) Қайталанудың барлық жағдайлары (5) жоғарылаған жиек ішек ісіктерінде табылған, төмендеген ішек ісіктері байқалған, қайталанулар байқалған жоқ $(p=0.021)$. Метастазды және өлімді зерттеу кезінде екі топ арасында статистикалық маңызды айырмашылықтар байқалмады.

қорытынды: Біз жоғарылаған жиек ішектің қатерлі ісілі кезіндегі қайталанулардың жиілігі мен лимфотармырлық инвазия төмендеген жиек ішектің обырымен салыстырғанда жоғары екенін анықтадық.

Негізгі сөздер: тоқ ішек қатерлі ісігі, төмендеген жиек ішек, қатерлі ісік нәтижелері, рецидив,жоғарылаған жиек ішек, тірі қалу 
СРАВНЕНИЕ ОНКОЛОГИЧЕСКИХ РЕЗУЛЬТАТОВ ПОСЛЕ КЛИНИЧЕСКИ РАДИКАЛЬНОЙ РЕЗЕКЦИИ ПРИ РАКЕ ВОСХОДЯЩЕЙ И НИСХОДЯЩЕЙ ОБОДОЧНОЙ КИШКИ

Э.М. Йылмаз ${ }^{1}$, Э. Каракан ${ }^{2}$, Б. Йылдыз ${ }^{1}$, М. Демир ${ }^{1}$, А.Э. Демиркиран ${ }^{1}$

'Кафедра общей хирургии, Университет имени Аднана Мендереса, Айдын, Турция

${ }^{2}$ Отделение общей хирургии, Государственная больница, Айдын, Турция

\section{PЕЗЮME}

Введение: Рак восходящей и нисходящей ободочной кишки имеет разные генетические и клинические характеристики. Считается, что рак восходящей ободочной кишки имеет более агрессивное течение.

Цель: Сравнить различия между раком восходящей и нисходящей ободочной кишки, онкологические результаты, выживаемость после клинически радикальной резекции.

Материалы и методы: Пациенты, прооперированные в период с января 2015 года по декабрь 2019 года, были включены в исследование и разделены на две группы, рак восходящей и нисходящей ободочной кишки. Изучены медицинские карты пациентов, и в дополнение к демографическим данным, зарегистрирована и сравнена такая информация, как стадия опухоли в зависимости от опухоли, узла, метастазирования, количество удаленных лимфатических узлов, тип операции (лапароскопическая/открытая), среднее время наблюдения, метастазы, рецидивы и смерть/выживаемость.

Результаты: Всего в исследование было включено 76 пациентов, и у 38 (50\%) был диагностирован рак восходящей ободочной кишки, тогда как у 38 (50\%) был рак нисходящей ободочной кишки. Среднее время наблюдения составило 17,14 месяца (1-60 месяцев). Несмотря на то, что различий между двумя группами в отношении нервно-сосудистой инвазии обнаружено не было, среднее число позитивности

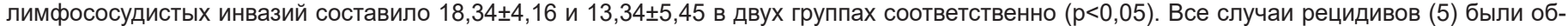
наружены при опухолях восходящей ободочной кишки, при раке нисходящей ободочной кишки рецидивов не наблюдалось ( $p=0,021)$. При исследовании метастазирования и уровня смертности, статистически значимых различий между двумя группами не наблюдалось.

Заключение: Мы обнаружили, что лимфососудистая инвазия и частота рецидивов выше при раке восходящей ободочной кишки по сравнению с раком нисходящей ободочной кишки.

Ключевые слова: рак ободочной кишки, нисходящая ободочная кишка, онкологические результаты, рецидив, восходящая ободочная кишка, выживаемость

\section{Introduction}

Colorectal cancers are among the prevalent cancers across the world [1]. The definitive curative treatment in colon cancer is surgery, and surgical methods such as right hemicolectomy, extended right hemicolectomy, left hemicolectomy and anterior resection can be applied according to the tumor localization [2]. Today, it is known that the origins and symptoms of right colon and left colon cancers differ [3]. While right colon tumors are polypoid and occult-bleeding tumors growing exophytically into the lumen, left colon tumors appear rather as tumors which obstruct the lumen, holding the wall and leading to fresh bleeding [3]. Moreover, they may present chromosomal and genetic mutational differences and differ in respect of the response to chemotherapy and the aggressive course [4].

In this study, our aim is to compare the oncological followups and surveys of right and left colon tumors following the surgical resection, and to analyze them.

\section{Material and methods}

The patients who had been operated by the same surgeons in the Adnan Menderes University, Faculty of Medicine, General Surgery Department between January 2015 and December 2019 were included in the study. The patients who had been diagnosed with right and left colon cancers and therefore operated were included in the study, and the tumors from the cecum up to proximal $2 / 3$ of the transverse colon were defined as right colon tumors (Group 1), and the tumors from the splenic flexure in the distal $1 / 3$ of the transverse colon to the rectum were designated as left colon tumors (Group 2). Urgently operated cases, cases at Stage 4 and subjected to neoadjuvant treatment and those with rectal cancer were excluded from the study.

Beside the demographic data of the patients, tumor stages according to the TNM staging, the number of lymph nodes removed, the type of the operation (laparoscopic/open), average follow-up time, metastasis, recurrence and death/survival were recorded, and statistical analysis was performed upon the comparison of both groups.

\section{Statistical analysis}

For data evaluation, the SPPS 25 (IBM Corp. Released 2017, IBM SPSS Statistics for Windows, Version 25.0. Armonk, NY: IBM Corp.) statistical packaged program was used. The variables were stated using the mean \pm standard deviation, percentage and frequency values. The variables were evaluated after the prerequisites for normality and homogeneity of variance were checked (Shapiro-Wilk and Levene's Test). In data analysis, the independent two-group t-test (Student's t-test) was used for the comparison of both groups, and the Mann Whitney-U test was performed when the prerequisites were not met. The categorical data were analyzed via Fisher's Exact Test and ChiSquare Test. In cases where the expected frequencies were below 20\%, the evaluation was made through the "Monte Carlo Simulation Method" in order to include these frequencies in the analysis. $\mathrm{p}<0.05$ and $\mathrm{p} 0.01$ were accepted as the significance level of the tests.

\section{Results}

The study is a retrospective file scan and included a total of 76 patients. 45 of the patients were men $(59.2 \%)$ and $31(40.8 \%)$ were women. Whereas $38(50 \%)$ of the patients were diagnosed with right colon cancer, $38(50 \%)$ were diagnosed with left colon cancer. $47(61.8 \%)$ of these cases were operated with the laparoscopic method, however, 29 (38.2\%) were operated with the open method. When the TNM stages are considered, 16 patients $(21.3 \%)$ were at T2, $46(61.3 \%)$ were at T3, $13(17.3 \%)$ were at T4, $44(58.7 \%)$ were at N0, $17(22.7 \%)$ were at N1 and $14(18.7 \%)$ were at N2. All the cases $(100 \%)$ had M0. During the follow-ups, recurrence was detected in 5 cases $(6.6 \%)$ and metastasis in 10 cases $(13.2 \%)$, but 7 cases $(9.2 \%)$ died (Table $1)$.

When the average follow-up time was 17.14 months (1 - 60 months), the mean $\mathrm{T}$ stage of the right colon tumors was found as $2.95 \pm 0.52$, and that of the left colon tumors as $2.97 \pm 0.73$. $(\mathrm{p}=0.860)$ the $\mathrm{N}$ stage was respectively detected as $0.61 \pm 0.79$ in right colon tumors and $0.59 \pm 0.8$ in left colon tumors $(\mathrm{p}=0.950)$. Neurovascular invasion positivity was found to be $14.32 \pm 4.16$ in the right colon tumors while it was $12.24 \pm 1.5$ in the left 
Table 1

Patient characteristics

\begin{tabular}{|c|c|c|c|}
\hline & & $\mathrm{n}$ & $\%$ \\
\hline \multirow[t]{2}{*}{ Gender } & Male & 45 & 59.2 \\
\hline & Female & 31 & 40.8 \\
\hline \multirow[t]{2}{*}{ Colon } & Right Colon & 38 & 50.0 \\
\hline & Left Colon & 38 & 50.0 \\
\hline \multirow[t]{2}{*}{ Surgery type } & Open Surgery & 29 & 38.2 \\
\hline & $\begin{array}{l}\text { Laparoscopic } \\
\text { Surgery }\end{array}$ & 47 & 61.8 \\
\hline \multirow[t]{2}{*}{ Recurrence } & None & 71 & 93.4 \\
\hline & Detected & 5 & 6.6 \\
\hline \multirow[t]{2}{*}{ Metastasis } & No & 66 & 86.8 \\
\hline & Yes & 10 & 13.2 \\
\hline \multirow[t]{3}{*}{$\mathrm{T}$} & 2,00 & 16 & 21.3 \\
\hline & 3,00 & 46 & 61.3 \\
\hline & 4,00 & 13 & 17.3 \\
\hline \multirow[t]{3}{*}{$\mathrm{N}$} & 0,00 & 44 & 58.7 \\
\hline & 1,00 & 17 & 22.7 \\
\hline & 2,00 & 14 & 18.7 \\
\hline \multirow[t]{2}{*}{ Mortality } & Present & 7 & 9.2 \\
\hline & Absent & 69 & 90.8 \\
\hline
\end{tabular}

Table 2 Lymph node involvement and invasion characteristics according to tumor localization

\begin{tabular}{|l|l|l|l|}
\hline & Right colon & Left colon & $\mathrm{p}$ \\
\hline & $\mathrm{n}=38$ & $\mathrm{n}=38$ & \\
\hline Age & $63.87 \pm 13.61$ & $67.63 \pm 12.93$ & 0.220 \\
\hline $\begin{array}{l}\text { Lymph node } \\
\text { Involvement }\end{array}$ & $2.34 \pm 4.16$ & $2.66 \pm 5.45$ & 0.780 \\
\hline $\begin{array}{l}\text { Neurovascular } \\
\text { invasion }\end{array}$ & $13.34 \pm 5.45$ & $12.24 \pm 1.5$ & 0.780 \\
\hline $\begin{array}{l}\text { Lymphovascular } \\
\text { invasion }\end{array}$ & $18.34 \pm 4.16$ & $13.34 \pm 5.45$ & $<0.05$ \\
\hline $\begin{array}{l}\text { Follow-up time, } \\
\text { months }\end{array}$ & $16.39 \pm 11.92$ & $17.89 \pm 12.61$ & 0.600 \\
\hline
\end{tabular}

colon tumors $(\mathrm{p}=0.780)$. Lymphovascular invasion positivity was found to be $18.34 \pm 4.16$ and $13.34 \pm 5.45$ in the two groups, respectively $(\mathrm{p}<0.05)$ (Table 2$)$.

While all the recurrences were detected at five patients $(100 \%)$ in right colon tumors, there was no recurrence in left colon tumors $(p=0.021)$. When the metastasis and death rates were examined, no statistically significant difference was seen between the two groups (Table 3).

Table 3 Non illness survival, metastasis and recurrence according to tumor localization

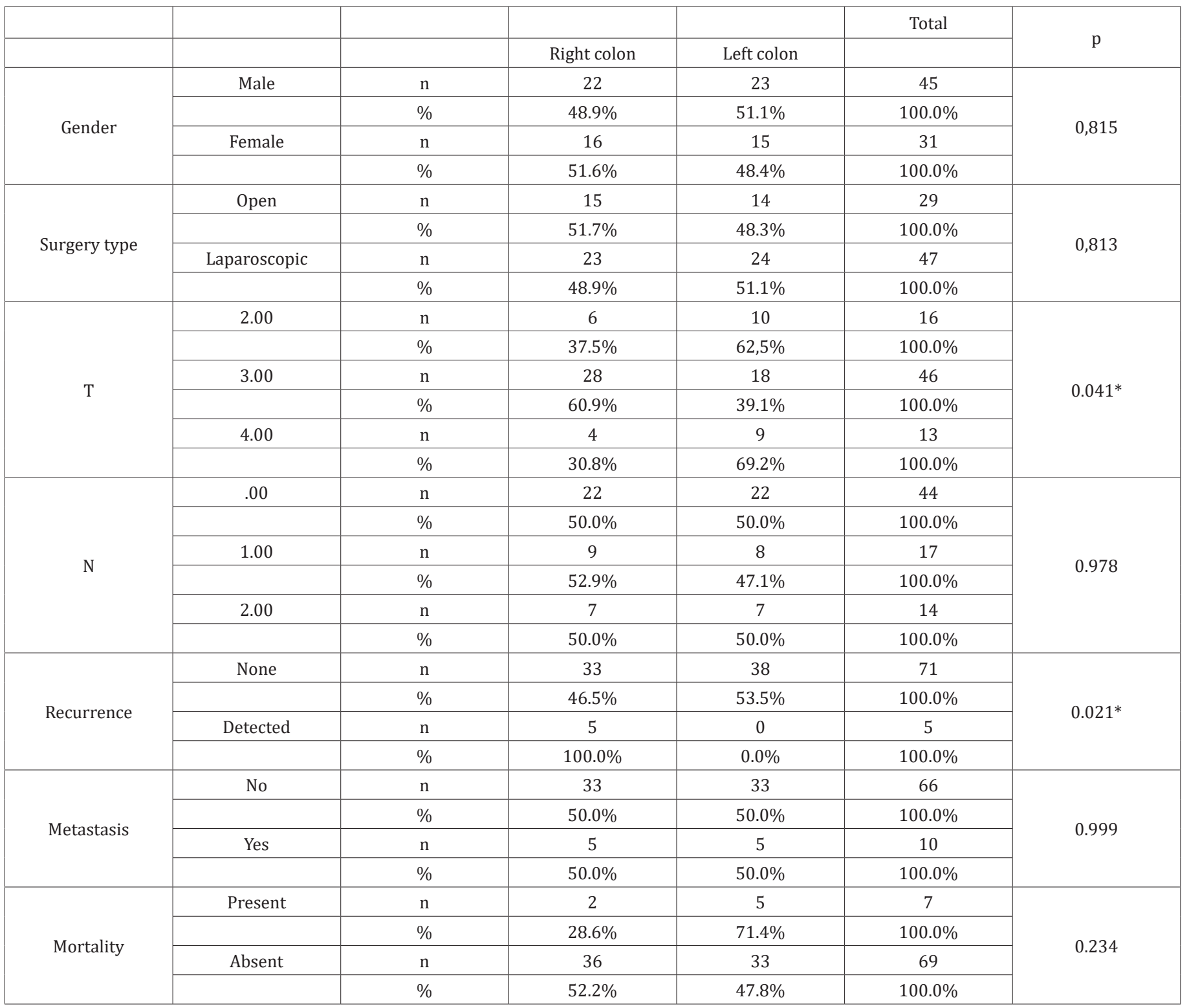




\section{Discussion}

It is known that right and left colon tumors exhibit different genetic characteristics and clinicopathological behaviors today [2]. In the literature, many studies have reported that right colon tumors are larger in size, in worse differentiation and in older patients compared to left colon tumors when the diagnosis is established [5-7]. While it is assumed that this generally results from the larger diameter of the right colon, the more insidious progress of the tumor than the left one and revealing a later finding, it is now thought that it is caused by molecular differences [8]. Because the right and left colons are developed from two different embryological sections such as midgut and hindgut, the tumors of this region are also influenced by the specific protein expressions of these regions and exhibit diversity and differences $[9,10]$.

Upon the review of the epidemiological studies today, it is believed that the risk factors including low physical activity and meat consumption and protective factors such as aspirin have different effects according to the anatomical regions [11]. Gene expressions differ as per localization, but the right colon cancers are frequently observed with the BRAF mutation, high microsatellite instability (MSI) and $\mathrm{CpG}$ island methylation, and left colon cancers are often observed with the p53 and KRAS mutations [12-14]. This is a significant factor that explains the differences. In a study conducted by Dae et al. [2], the right and left colon cancers were compared, and no difference was found between the $\mathrm{T}$ stages, however, the $\mathrm{N}$ stages were found higher in the right colon cancers. In the study conducted by Mik et al. [15], an average of 8 lymph nodes were removed in the left colon tumors, and this number was 11 in the right colon tumors; the probability of malignant incidence was explained to be higher in right colon tumors. In our study, no statistically significant difference was detected between the $\mathrm{T}$ and $\mathrm{N}$ stages, but the rate of lymphovascular invasion was observed to be higher in right colon tumors. We think that the diameter of the tumor, its invasion into the intestinal wall and the lymph node metastasis are directly proportional. While, in our study, the T3 tumors were higher in right colon cancers in isolation, we think that the reason for the lack of difference in T stages when two groups were compared was their early diagnosis, which reduced the possibility of lymph node metastasis.

After colon cancers are curatively resected, the most frequent risk of recurrence covers the first 2 years, and close follow-up is very important for disease-free follow-up and survey. In the study of Powel et al. [6] on 411 colorectal cancer patients, they divided the patients into localization as right colon, left colon and rectum, followed them closely following the surgery, and the average survey was reported as 115 months for the right colon, and 127 months for the left colon, and there was no significant difference between them. In the study conducted by Dae et al. [2], the 5-year post-operative surveys of right colon tumors and left colon tumors were put forward as $88.7 \%$ and $82.1 \%$, respectively, however, their disease-free survival as well as right colon tumors were reported to be worse. In our study, the average follow-up time was 17.14 months (1 - 60 months), but recurrence was observed in 5 patients and all of them had right colon cancer. Whereas $50 \%$ of the metastases were in the right colon, $50 \%$ were seen in the left colon tumors and 7 of these patients with metastasis and recurrence died. Our disease-free survival rate was $80.2 \%$, and it was compatible with the literature. We also believe that the observation of all our recurrence cases in right colon cancers result from the mucin secretion in these localization tumors, and worse genetic expressions and subtypes [16].

Consequently, right colon cancers have worse differentiations than left colon cancers, have a worse prognosis and emerge at an older age. These cancers can be diagnosed later, and their treatment may require differences due to genetic subtypes. For this reason, it is necessary to be on alert in terms of recurrences and genetic screenings after the right colon cancer surgeries.

\section{Limitations in the study}

For this study, which was retrospective, whether patients received chemotherapy, and if they did, how much and from which protocols they received it could not be learnt properly by phone. As some patients reject chemotherapy, this constitutes a significant limitation that may affect the results of this study. Therefore, we suggest and plan the execution of more centered, randomized and prospective studies including genetic tests if possible.

Disclosures: There is no conflict of interest for all authors.

\section{References}

1. Brenner H, Kloor M, Pox CP. Colorectal cancer. Lancet. 2014; 383:1490-502 https://doi.org/10.1016/S0140-6736(13)61649-9

2. Dae RL, Jung KK, Taehyung K, Eung JS. Comparison of oncological outcomes of right- sided colon cancer versus left-sided colon cancer after curative resection. Which side is better outcome? Medicine (Baltimore). 2017; 96(42): e8241. https://doi.org/10.1097/ MD.0000000000008241

3. Bale AL, Penney MD, Allison MC. The prevalence of iron deficiency among patients presenting with colorectal cancer. Colorectal Dis. 2005; 7:398-402 https://doi.org/10.1111/j.1463-1318.2005.00789.x

4. Baran B, Özüpek NM, Tetik NY, Bekçioğlu O, Baskın Y. Difference Between Left-Sided and Right-Sided Colorectal Cancer: A Focused Review of Literature. Gastroenterology Res. 2018; 11(4): 264-273. https://doi.org/10.14740/gr1062w

5. Benedix F, Kube R, Meyer F, Schmidt U, Gastinger I, Lippert H et al. Comparison of 17,641 patients with right- and left-sided colon cancer: differences in epidemiology, perioperative course, histology, and survival. Dis Colon Rectum. 2010; 53(1):57-64. https://oi. org/10.1007/DCR.0b013e3181c703a4

6. Powell AG, Wallace R, McKee RF, Anderson JH, Going JJ, Edwards J et al. The relationship between tumour site, clinicopathological characteristics and cancer-specific survival in patients undergoing surgery for colorectal cancer. Colorectal Dis. 2012; 14(12):1493-9. https://doi.org/10.1111/j.1463-1318.2012.03048.x

7. Saltzstein SL, Behling CA. Age and time as factors in the left to right shift of the subsite of colorectal adenocarcinoma: a study of 213,383 cases from the California Cancer Registry. J Clin Gastroenterol. 2007; 41:173-7. https://doi.org/10.1097/01.mcg.0000225550.26751.6a 
8. Shen H, Yang J, Huang Q, Jiang MJ, Tan YN, Fu JF et al. Different treatment strategies and molecular features between right-sided and left-sided colon cancers. World J Gastroenterol. 2015; 7;21(21):6470-8. https://doi.org/10.3748/wjg.v21.i21.6470

9. MissiagliaE,JacobsBD,ArioG. Distal and proximal colon cancers differ in terms of molecular, pathological, and clinical features. Ann Oncol. 2014; 25:1995-2001. https://doi.org/10.1093/annonc/mdu275

10. Meguid RA, Slidell MB, Wolfgang CL. Is there a difference in survival between right- versus left-sided colon cancers? Ann Surg Oncol. 2008; 15:2388-2394. https://doi.org/10.1245/s10434-008-0015-y

11. Moradi T, Gridley G, Björk J, Dosemeci M, Ji B-T, Berkel HJ, et al.Occupational physical activity and risk for cancer of the colon and rectum in Sweden among men and women by anatomic subsite. Eur J Cancer Prev. 2008; 17(3):201-8. https://doi.org/10.1097/ CEJ.0b013e3282b6fd78

12. Tran B, Kopetz S, Tie J, Gibbs P, Jiang ZQ, Lieu CH, et al. Impact of BRAF mutation and microsatellite instability on the pattern of metastatic spread and prognosis in metastatic colorectal cancer. Cancer. 2011; 117(20):4623-32. https://doi.org/10.1002/cncr.26086

13. Sinicrope FA, Shi Q, Smyrk TC, Thibodeau SN, Dienstmann R, Guinney J, et al. Molecular markers identify subtypes of stage III colon cancer associated with patient outcomes. Gastroenterology. 2015; 148(1):88-99. https://doi.org/10.1053/j.gastro.2014.09.041

14. Roth AD, Tejpar S, Delorenzi M, Yan P, Fiocca R, Klingbiel D, et al. Prognostic role of KRAS and BRAF in stage II and III resected colon cancer: results of the translational study on the PETACC-3, EORTC 40993, SAKK 60-00 trial. J Clin Oncol. 2010; 28(3):466-74. https://doi.org/10.1200/JCO.2009.23.3452

15. Mik M, Berut M, Diziki L, Trzcinski R, Dziki A. Right- and left-sided colon cancer - clinical and pathological differences of the disease entity in one organ Arch Med Sci. 2017; 13(1):157-162. https://doi.org/10.5114/aoms.2016.58596

16. Lee MS, Menter DG, Kopetz S. Right Versus Left Colon Cancer Biology: Integrating the Consensus Molecular Subtypes. J Natl Compr Canc Netw. 2017; 15(3):411-419. https://doi.org/10.6004/jnccn.2017.0038

How to cite this article: Eyüp Murat Yilmaz, Erkan Karacan, Buse Yildiz, Murat Demir, Ahmet Ender Demirkiran. Comparison of oncological results after curative resection in right and left colon cancers. J Clin Med Kaz. 2020; 2(56):41-45 